\title{
SUCCESS FACTORS OF BANGKIT BERSAMA COOPERATIVE ORGANIZATION FOR COMMUNITY EMPOWERMENT BASED ON SCHMUCK THEORY
}

\author{
Eka Purwasi Ivanka ${ }^{1}$ dan Jafar Sembiring ${ }^{2}$ \\ Master of Management Program, Telkom University Indonesia \\ 1 eka.purwasi.ivanka@gmail.com \\ 2 jafar.sembiring@gmail.com
}

\begin{abstract}
Cooperative is one of the institutions that are in accordance with the development of rural communities as an effort to empower the economy of the people or the society. Bangkit Bersama Cooperative was established based on the community's concern about the environmental damage in Waduk Saguling Sungai Citarum. This cooperative body is considered successful in utilizing Saguling reservoir for the welfare of its members. The present study aims to identify and measure the significance of success factors of Bangkit Bersama Cooperative.

Data is gathered through questionnaires administered directly, through the Chairman of Bangkit Bersama Cooperative, to 193 members of the organization. The management and administrators of Bangkit Bersama Cooperative are not included in the sample. All questionnaires are complete and valid to be processed. Validity and reliability tests are conducted before the data is processed. Data is processed using confirmatory factor analysis technique.

The result of confirmatory factor analysis proves that there are six factors that significantly positive in measuring the success of Bangkit Bersama Cooperative. The six factors are: clarifying communication, establishing goals, uncovering and working with conflict, improving group procedure in meetings, solving the problem, and assessing changes.
\end{abstract}

Keywords: Success, Confirmatory, Significant

\section{INTRODUCTION}

The organization is not always a company or enterprise. Cooperative body is also an organization. It is an autonomous organization founded by a group of people voluntarily working together to satisfy the economic, social, and cultural needs and aspirations together through business activities owned and managed democratically (Hendar, 2010: 2). Bangkit Bersama Cooperative is an organization founded based on people's concern towards the environmental and economic condition of the people in the community, whose average income is low. The Cooperative management expects that Bangkit Bersama Cooperative will be able to help to solve these problems. Based on the overview, profile, financial report, and membership of 
Bangkit Bersama Cooperative year by year, it can be concluded that Bangkit Bersama Cooperative is one of the successful cooperative institutions. In 2009, the total membership of the cooperative is 20 people. When the present study is conducted, the total number of members and management is 201 people, with an annual income of almost IDR 600 million.

\section{LITERATURE REVIEW}

\subsection{Organizational Success}

The organization is a formal group of people, with their own individual motives (salary, benefit, work satisfaction), who work together in a certain process to achieve a common goal (Mulyadi, 2015: 6). This definition is in line with that outlined by Nurhasanah and Wisnu (2005: 3), that organization is a vessel that people use individually or collectively to achieve goals. Meanwhile, Rucii (2008) in Hardiningtyas (2016: 7) notes that basically organization can be defined in two terms: organization in a static form, i.e. something that is not moving, and organization in a dynamic form, i.e. a living organism, a dynamic organism, or a cooperative process of people who belong to a certain group to achieve common goals.

The success of an organization depends on the effort of organizational development (Schmuck, 1971: 2). Therefore, organizational success can be measured through some factors. The most common factors to measure organizational success are seven factors formulated by Schmuck, et al (1977). The following are the definitions of the seven factors.

1) Clarifying communication

Communication skill serves to build a good relationship in a subsystem. Communication is clearly very critical for organizational success. Selfdevelopment of information delivery and information receiving methods in sub-system level may cause ambiguity and conflicts of norms and roles. Clear communication will develop openness and trust between individuals. Communication consists of five (5) elements: a. communicator (a speaker, deliverer of the message), b. message delivery (in this case can be done by speaking, sending, or broadcasting it), c. messages (in the form of commands, reports, or suggestions), d. communicate (the intended recipient, the responder, or the audience of a message), and e. response (in the form of action or reaction) (Redfield, C. E., in Wursanto, 2005: 157).

2) Establishing goals

In terms of achieving goals, pluralism of objectives in a sub-system is an important part of achieving common goals. Organization members may learn how to explain and describe the goals and improve their sense of belonging to them. Thus, members of the organization will be inspired to integrate their efforts to realize the objectives. In the process of achieving its goals, the organization is affected by several factors, including leadership process, motivation, communication system, interaction-influence process, 
decision-making process, formulation and achievement of goals (Hoy and Miskel, in Soetopo, 2012: 59).

3) Uncovering and working with conflict

The effort to perform communication clarification and goal setting will cause an increase in conflict-awareness. Openness towards conflicts will facilitate the clarification of norms and roles that will help the organization in completing its tasks. The norms for collaboration can replace conflictavoiding norms. Individuals' roles can improve motivation and utilize various skills and value systems. The sources of conflicts are a) communication problem, which occurs in each and in the combination of communication elements (source of communication, message, message recipient, and communication channel), b) organizational structure, which has the potential to cause conflicts. Each department/function in an organization has its own purpose, interest, and programs, which are often different from one another, c) human factor, i.e. the varied and unique nature and personality of a human being (Smit et.al in Sopiah, 2008: 60).

4) Improving group procedure in meetings

Face-to-face interaction in group meetings is very useful. Unproductive and unprocedural organizational activities, aimed to facilitate the productivity of tasks and group maintenance may make the meetings more interesting. Meetings may serve as an integration tool if the members of the group apply problem-solving procedures to maximize the utilization of available human resources.

5) Solving problems

Adaptation implies a continuous active involvement in the cycle of problemsolving to identify, analyze, and act for environmental contingency. Subsystems that utilize human resources to take creative solution are more successful in finding solutions, compared to those who only consider the practices of the past. Improvement in collaborative skills can develop the confidence to take risks in trying new ways to reforms the vital functions of the organization.

6) Making decisions

An effective subsystem, like an adopting organization, should be able to make decisions. Actions can only be done effectively if the person understands clearly what decision he has to take and is committed to implementing it. Although it is not necessary to influence others, it may reduce authority if a decision is made without being based on adequate knowledge and competence.

7) Assessing changes

Changes for personal purposes may not result in an adaptation. The organization has to develop criteria to measure and evaluate the progress of goals achievement, both in the short term and in the long term. The organization should be more aware and able to analyze the content and process of the changes. 


\section{RESEARCH METHODOLOGY}

Research methodology implemented in the present study is the quantitative method, using descriptive statistic data analysis and confirmatory factor analysis. Descriptive statistic technique is applied to describe respondents' characteristics. In addition, a descriptive statistic with percentage technique is also implemented to discover the implementation level of organization's success factors.

The measurement of organization's success factors' significance is done through confirmatory factor analysis. Confirmatory factor analysis is an analysis implemented to test unidimensionality, validity, and reliability of construct measurement model which cannot be directly observed (Joreskog and Sorbom, in Kusnendi, 2008: 98). Confirmatory factor analysis can be developed to analyze more than one factor or latent variables at the same time, including the independent latent variables and the dependent latent variables (Sugiarto, 2006: 77).

The population in this study is all 193 members of Bangkit Bersama Cooperative (Bangkit Bersama Cooperative, 2017). The sampling technique implemented in the present study is the census technique, in which all members of Bangkit Bersama Cooperative are used as a sample of the study. The eight management and administrators of Bangkit Bersama Cooperative are not included in the population or the sample.

\section{FINDINGS AND DISCUSSION}

\subsection{Respondents' Characteristics}

Based on gender, the number of male members and female members is almost equal. The number of male members is a little higher $(52 \%)$ than the female members (48\%). Based on age, most of the members are between 35 and 45 years old $(33 \%)$. Based on the level of education, most of the members have primary school education (80\%). Based on the duration of membership, most members have joined the cooperative for one to four years.

\subsection{Descriptive Analysis}

The result of descriptive analysis using percentage technique can be seen in the following table. 
Table 1

Descriptive Analysis of Organization's Success Factors

\begin{tabular}{|l|c|c|c|c|}
\hline \multicolumn{1}{|c|}{ Sub-Variable } & Score & Ideal Score & Percentage Score & Category \\
\hline Clarifying communication & 602.7 & 772 & $78.06 \%$ & High \\
\hline Establishing goals & 613 & 772 & $79.40 \%$ & High \\
\hline $\begin{array}{l}\text { Uncovering and working with } \\
\text { conflict }\end{array}$ & 584 & 772 & $75.64 \%$ & High \\
\hline $\begin{array}{l}\text { Improving group procedure in } \\
\text { meetings }\end{array}$ & 611 & 772 & $79.14 \%$ & High \\
\hline Solving Problems & 594.6 & 772 & $77.02 \%$ & High \\
\hline Making decisions & 586.7 & 772 & $75.99 \%$ & High \\
\hline Assessing changes & 635 & 772 & $82.25 \%$ & Very High \\
\hline Means & 603.9 & 772 & $78.22 \%$ & High \\
\hline
\end{tabular}

Remark: $n=193$; ideal score $=772$

In Table 1, it can be seen that based on the perception of Bangkit Bersama Cooperative members, the implementation of organization's success factors is in the High category. The success factor with the highest percentage, and belongs to a Very High category is the assessing change factor. It means that cooperative members think that they are always encouraged to be better, are always empowered to continuously do better.

\subsection{Data Processing Result}

Six organization's success factors are tested using second-order confirmatory factor analysis (SOCFA) with LISREL software. SOCFA is a two-tiered measurement model. The first tier shows the correlation between items in the questionnaire (measurable variable) and organization's success factors as the latent variable. The second tier measures the correlation between organization's success factors (measurable variables) and organizations' success (latent variable). Data processing result shows the construct implemented to develop a research model. Data processing result meets the previously set criteria of Goodness of Fit (GOF).

The goodness of fit analysis of the overall model is as follow:

a. Chi-square value is 60.56 and $p=0.11>0.05$. NCP value is 12.56 , which is a quite high value, and $90 \%$ confidence interval of $\operatorname{NCP}(0.0,36.61)$ is narrow. Based on NCP, it can be concluded that the overall model is good.

b. RMSEA value of $0.037<0.08$ indicates the overall model fitness is in good fit and $90 \%$ confidence interval of RMSEA (0.0, 0.063). RSMEA value of 0.037 is in that interval. It means that RMSEA estimation has a good degree of precision. P-value for test of close fit (RMSEA $>0.05)=0.77>0.50$, indicating that the overall model is good fit because the $p$-value needed for test of close fit is $\geq 0,05$.

c. GFI value is 0.95 . It means that the model is a good fit because its GFI is higher than the cut off value of $\geq 0.90$. The AGFI value is 0.92 , indicating that the model is a good fit because the fit value for AGFI parameter is $\geq$ 0.90 . 
The result goodness of fit test of the model using SOCFA, with LISREL software, is detailed in Table 2.

Table 2

Result of the Overall Model Test of Goodness of Fit

\begin{tabular}{|l|l|c|l|}
\hline GOF VALUE & REFERENCE LEVEL & RESULT & CLOSE FIT LEVEL \\
\hline Chi-square & Low value & 60.56 & Good Fit \\
\hline P-value & $\mathrm{P}>0.05$ & 0.11 & Good Fit \\
\hline RMSEA & RSMEA $\leq 0.08$ & 0.037 & Good Fit \\
\hline P (close fit) & $\mathrm{P} \geq 0.05$ & 0.77 & Good Fit \\
\hline RMR & RMR $\geq 0.05$ & 0.018 & Very Good Fit \\
\hline GFI & GFI $\geq 0.90$ & 0.95 & Good Fit \\
\hline AGFI & AGFI $\geq 0.90$ & 0.92 & Good Fit \\
\hline CFI & CFI $\geq 0.90$ & 0.98 & Good Fit \\
\hline
\end{tabular}

In Table 2, it can be seen that the value of goodness of fit with Chi-square and the pvalue is $\leq 0.05$. It means that, based on all goodness of fit, the model meets the criteria of a good fit. It can be concluded that the level of acceptance and overall fit of the model is good. The GFI value of 0.95 , AGFI value of 0.92 , CFI value of 0.98 have met the fit criteria (more than 0.90) and the RMSEA value is 0.037 (less than 0.08). Overall, the model is acceptable.

Based on the data processing using SOCFA measurement, a path diagram results. In this diagram, the estimates value, factor weight value, and t-value can be seen. Below the diagram, the values of Chi-square, df, p-value, and RSMEA. The path diagram of SOCFA measurement result for Bangkit Bersama Cooperative's success factors is presented in Figure 1.

\section{Figure 1}

SOCFA Test Result for Bangkit Bersama Cooperative's Success in Factors' Weight Value

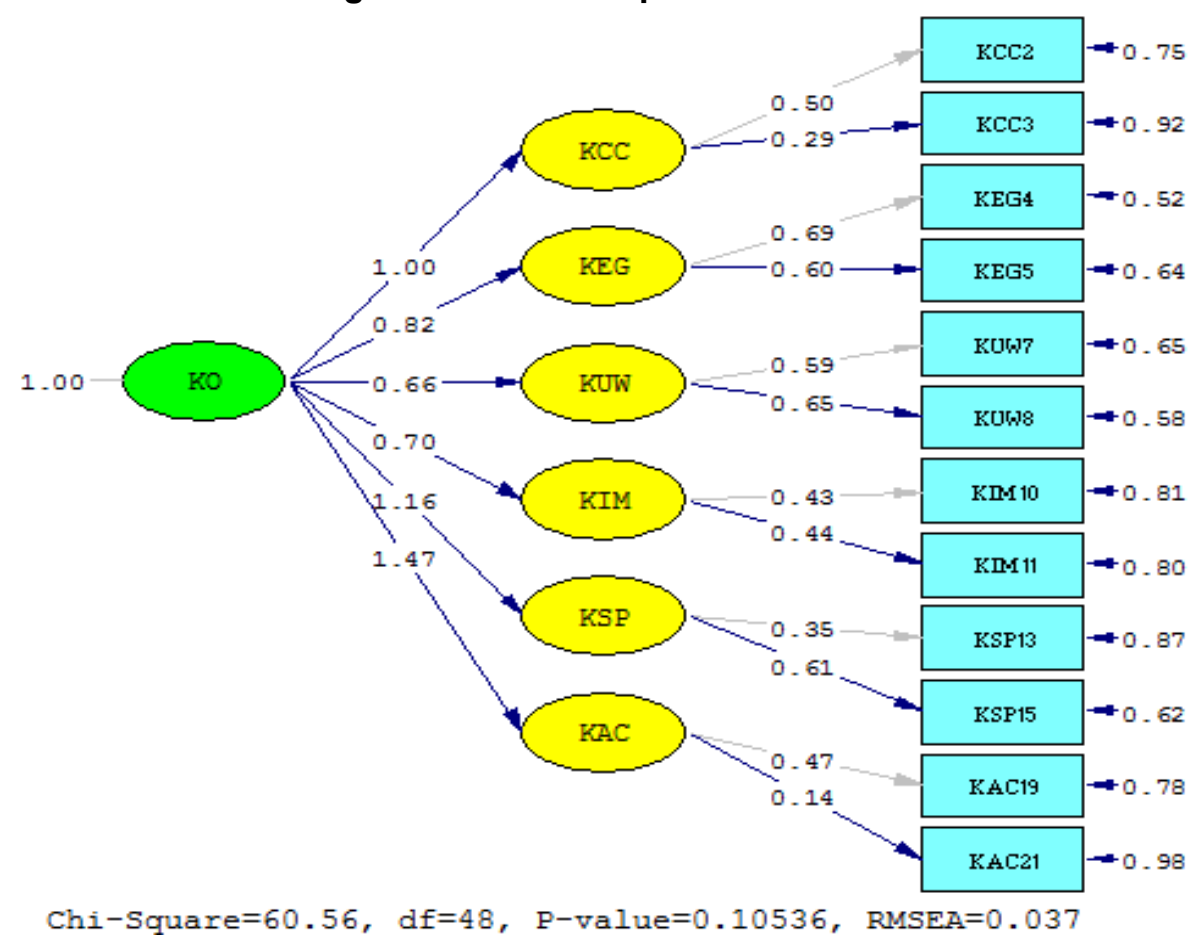


Figure 1 shows the factors' weight value. Factors' weight value indicates the validity coefficient. Figure 1 can be described as follow:

1. The factor of Clarifying Communication (KCC) is measured through two statements. Statement 1 is KCC2 (the use of common Cooperative terms/language) with factor's weight value of 0.50 . Statement 2 is KCC3 (clear job distribution) with factor's weight value of 0.29.

2. The factor of Establishing Goals (KEG) is measured through two statements. Statement 1 is KEG4 (understanding of objectives to achieve) with factor's weight value of 0.69 . Statement 2 is KEG5 (no desire to leave/stop being a member) with factor's weight value of 0.60 .

3. The factor of Uncovering and Working with Conflict (KUW) is measured through two statements. Statement 1 is KUW7 (objective conflict resolution) with factor's weight value of 0.59 . Statement 2 is KUW8 (conflict resolution through discussion) with factor's weight value of 0.65 .

4. The factor of Improving Group Procedure in Meetings (KIM) is measured through two statements. Statement 1 is KIM10 (working together in performing tasks) with factor's weight value of 0.43 . Statement 2 is KIM11 (feeling safe and secure in working in a group) with factor's weight value of 0.44 .

5. The factor of Solving Problems (KSP) is measured through two statements. Statement 1 is KEG13 (finding the root of the problem) with factor's weight value of 0.35 . Statement 2 is KEG15 (solving problems by taking a wise solution/action) with factor's weight value of 0.61 .

6. The factor of Assessing Changes (KAC) is measured through two statements. Statement 1 is KAC19 (evaluation of finished activities) with factor's weight value of 0.47 . Statement 2 is KAC21 (product innovation/development to increase sale) with factor's weight value of 0.14 .

The path diagram of SOCFA test result in t-value for Bangkit Bersama Cooperative's success is presented in Figure 2.

Figure 2

SOCFA Test Result for Bangkit Bersama Cooperative's Success in t-value

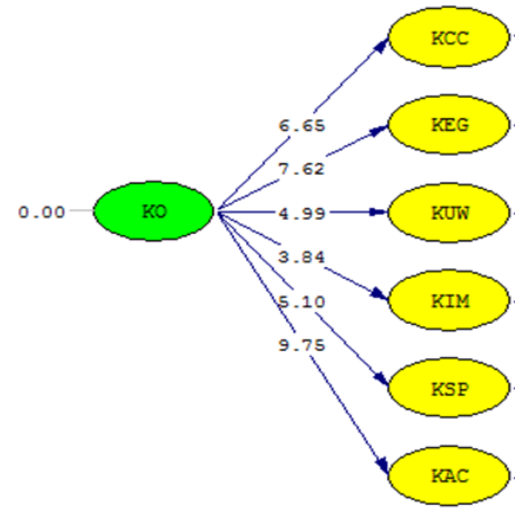

Chi-Square $=60.56, \mathrm{df}=48, \mathrm{P}-\mathrm{value}=0.10536, \mathrm{RMSEA}=0.037$ 
Figure 2 shows t-values. T-values indicate validity coefficient. T-value is considered valid if its $t$-calc is higher than its t-table (>1.96). In other words, $t$-values in this study indicate the significance level of the success factors of Bangkit Bersama Cooperative. Therefore, the t-values presented here are the $t$-values of the organization's success factors (the measurable variable) on organization's success (latent variable). Figure 2 can be described as follow:

1. The factor of Clarifying Communication (KCC) has t-calc higher than t-table (6.65>1.96). Therefore, KCC is significant in measuring organizational success $(\mathrm{KO})$.

2. The factor of Establishing Goals (KEG) has t-calc higher than t-table (7.62>1.96). Therefore, KEG is significant in measuring organizational success $(\mathrm{KO})$.

3. The factor of Uncovering and Working with Conflict (KUW) has t-calc higher than t-table $(4.99>1.96)$. Therefore, KUW is significant in measuring organizational success (KO).

4. The factor of Improving Group Procedure in Meetings (KIM) has t-calc higher than t-table $(3.84>1.96)$. Therefore, $\mathrm{KIM}$ is significant in measuring organizational success (KO).

5. The factor of Solving Problems (KSP) has t-calc higher than t-table $(5.10>1.96)$. Therefore, KSP is significant in measuring organizational success $(\mathrm{KO})$.

6. The factor of Assessing Changes (KAC) has t-calc higher than t-table $(9.75>1.96)$. Therefore, KAC is significant in measuring organizational success $(\mathrm{KO})$.

Based on the result of SOCFA Test on the success of Bangkit Bersama Cooperative, the result of this study model test is presented in Table 3 . The factors' weight value is the measurement of each item on organization's success factors, while the t-value is the measurement of each factor's significance on organizational success; in this case is the success of Bangkit Bersama Cooperative.

Table 3

Results of SOCFA Test in Factors' Weight Value and t-Value

\begin{tabular}{|c|c|c|c|c|}
\hline Variable & t-Value & Factor & Item & Factor Weight \\
\hline \multirow{12}{*}{$\mathrm{KO}$} & \multirow{2}{*}{9.75} & \multirow{2}{*}{$\mathrm{KAC}$} & KAC19 & 0.47 \\
\hline & & & KAC21 & 0.14 \\
\hline & \multirow{2}{*}{7.62} & \multirow{2}{*}{ KEG } & KEG4 & 0.69 \\
\hline & & & KEG5 & 0.60 \\
\hline & \multirow{2}{*}{6.65} & \multirow{2}{*}{$\mathrm{KCC}$} & KCC2 & 0.50 \\
\hline & & & KCC3 & 0.29 \\
\hline & \multirow{2}{*}{5.10} & \multirow{2}{*}{$\mathrm{KSP}$} & KSP13 & 0.35 \\
\hline & & & KSP15 & 0.61 \\
\hline & \multirow{2}{*}{4.99} & \multirow{2}{*}{ KUW } & KUM7 & 0.59 \\
\hline & & & KUW8 & 0.65 \\
\hline & \multirow{2}{*}{3.84} & \multirow{2}{*}{ KIM } & KIM10 & 0.43 \\
\hline & & & KIM11 & 0.44 \\
\hline
\end{tabular}


Remarks:

$\mathrm{KO}=$ Organizational Success

$\mathrm{KAC}=$ Assessing Changes

$\mathrm{KEG}=$ Establishing Goal

$\mathrm{KCC}=$ Clarifying Communication

$\mathrm{KSP}=$ Solving Problems

$\mathrm{KUW}=$ Uncovering and Working with Conflict

$\mathrm{KIM}=$ Improving Group Procedure in Meetings

\subsection{Discussion}

Based on Table 3, the most dominant factor is KAC (assessing changes), with tvalue of 9.75. The second most dominant factor is KEG (establishing goals), with tvalue of 7.62. The third is KCC (clarifying communication) with t-value of 6.65 . It means that, based on Schmuck theory, these three factors are the most dominant in determining the success of Bangkit Bersama Cooperative. Meanwhile, the other three factors of KSP (solving problems), KUW (uncovering and working with conflict), and KIM (improving group procedure in meetings) determine the success of Bangkit Bersama Cooperative with values of 5.10, 4.99, and 3.84, respectively. Each factor is described in detail as follow:

1. Clarifying Communication. In this factor, the KCC3 (clear job distribution) indicator is the lowest success factor of Bangkit Bersama Cooperative. This is probably due to the members' perception that the job description or task distribution in the cooperative is unclear. Not all members of Bangkit Bersama Cooperative fully understand the tasks that other divisions do. Most of them only know it in general, not in detail. A member who is fully and directly involved in the activities of Bangkit Bersama Cooperative will understand all the tasks and their distribution because job description and distribution in Bangkit Bersama Cooperative is very simple. All new members who wish to work in Bangkit Bersama Cooperative will receive a training and socialization to make them comprehend the jobs and task distribution clearly. However, since most of them have a low level of education (primary school graduates), it is relatively difficult for them to comprehend the tasks they have to do.

2. Establishing Goals. In this factor, the KEG5 (no desire to leave) indicator is the lowest success factor of Bangkit Bersama cooperative. It is because some of the members still believe that Cooperative is identical with savingsand-loans business. In fact, Bangkit Bersama Cooperative focuses more on the empowerment and management of surrounding environment, as well as on savings-and-loans using waste and garbage as the payment. The outdated assumptions of those members make them wish to leave the Cooperative, especially since the payment for loans is done using garbage or waste. Meanwhile, the members who fully accept the regulations of Bangkit Bersama Cooperative, regarding environmental empowerment and 
management and savings-and-loans with garbage payment, will be loyal. In other words, their desire to leave the cooperative will be low. On the other hand, the members who cannot accept that they pay their loan with garbage or waste will be likely to join other cooperatives that provide regular savingsand-loans services.

3. Uncovering and Working with Conflict. In this factor, the KUW7 (objective conflict resolution) indicator is the lowest success factor of Bangkit Bersama Cooperative. It is because some members consider the conflict resolution in the organization is not objective. Such opinion is formed because sometimes, a conflict resolution only involves the management and coordinators of Bangkit Bersama Cooperative. Conflict resolution involving all members is only implemented when the conflict is considered big or affecting the whole situation of Bangkit Bersama Cooperative, requiring input and suggestions of all members.

4. Improving group Procedure in Meetings. In this factor, the KIM10 (working together in performing tasks) indicator is the lowest success factor of Bangkit Bersama Cooperative. It is because most members think that the tasks are inter-divisional. In other words, they only work together with other divisions whose jobs are closely related to theirs. Working together is only performed to clean the surrounding environment. Such activity is performed only when some guests visit the Cooperative.

5. Solving Problems. In this factor, the KSP13 (finding the root of the problem) indicator is the lowest success factor of Bangkit Bersama Cooperative. It is because some members still believe that it is not that important to find the root of the problem to solve it. They believe that problems can be solved by following the existing rules and procedures and only involving management and coordinators of the Cooperative. Problem-solving that involves all members of Bangkit Bersama Cooperative is only conducted when the problem affects all aspects of the Cooperative and requires input from all members. Such problem solving is usually implemented at the annual meeting.

6. Making decision. In this factor, there is no significant value to measure the success of Bangkit Bersama Cooperative. It is because the decision-making process does not involve all members of the Cooperative. The membersonly provide suggestions. The decisions are made by the management based on what effects they will produce and referring to the existing rules and regulations of Bangkit Bersama Cooperative.

7. Assessing Changes. In this factor, the KAC21 (product innovation/development to improve sale) is the lowest success factor of Bangkit Bersama Cooperative. It is because some members still think that savings-and-loans business should involve money, not garbage or waste. Such belief makes it hard to do product innovation/development. Although this factor is critical in the success of Bangkit Bersama Cooperative, the level of innovation is very low. Most members think that since cooperatively is 
identical with savings-and-loans business, it does not need any innovation. In fact, Bangkit Bersama Cooperative is a production cooperative that aims to empower people and maintain the environment. In other words, its innovation should be high.

\section{CONCLUSIONS AND SUGGESTIONS}

\subsection{Conclusions}

Based on the result of data processing and discussion, and to answer the research problem, the following conclusions are presented:

1. The implementation of organization's success factors based on Bangkit Bersama Cooperative members' perception is in the High category. This indicates that both the members and the management of Bangkit Bersama Cooperative wish to improve Bangkit Bersama Cooperative.

2. The six organization's success factors that are significant in determining Bangkit Bersama Cooperative's success are Assessing Changes, Establishing Goals, Clarifying Communication, Solving Problems, Uncovering and Working with Conflict, and Improving group Procedure in Meetings.

3. One factor that is not significant in determining the success of Bangkit Bersama Cooperative is Making a decision.

\subsection{Suggestions}

Based on data processing, the following suggestions are proposed.

1. It is important for the management of Bangkit Bersama Cooperative to do more in terms of socializing its product innovation or development to improve sale.

2. The management of Bangkit Bersama Cooperative should be more responsive and more aware of inputs from the members so that the latter will be more involved in improving Bangkit Bersama Cooperative.

3. Future researchers on the success of Bangkit Bersama Cooperative and other cooperatives should be conducted using other factors, particularly those used in cooperative success measurement in Indonesia. 


\section{REFERENCES}

Hardiningtyas, D. 2016. Psikologi Organisasi. Bahan Perkuliahan Ekonomi Manajemen, Universitas Brawiwjaya.

Hendar. 2010. Manajemen Perusahaan Koperasi Pokok-pokok Pikiran Mengenai Manajemen dan Kewirausahaan Koperasi. Jakarta: Erlangga.

Kusnendi. 2008. Model-model Persamaan Struktural Satu dan Multigroup Sampel Dengan Lisrel. $1^{\text {st }}$ ed. Bandung: CV. Alfabeta.

Mulyadi. 2015. Perilaku Organisasi dan Kepemimpinan Pelayanan. Bandung: CV Alfabeta.

Nurhasanah, S., \& Wisnu, D.U.R. 2005. Teori Organisasi Struktur dan Desain. $1^{\text {st }}$ ed. Malang: Universitas Muhammadiyah Malang.

Riduwan. 2014. Metode dan Teknik Menyusun Tesis. $10^{\text {th }}$ ed. Bandung: CV Alfabeta.

Sanusi, A. 2011. Metodologi Penelitian Bisnis. Jakarta: Salemba Empat.

Schmuck, R.A., et al. 1977. The Second Handbook of Organization Development in Schools. California: Mayfield Publishing Company.

Sekaran, U. 2006. Research Methods for Business. $4^{\text {th }}$ ed. Book 2. Jakarta: Salemba Empat.

Soetopo, H. 2012. Perilaku Organisasi Teori dan Praktek di Bidang Pendidikan. Second Edition. Bandung: PT. Remaja Rosda Karya.

Sopiah. 2008. Perilaku Organisasional. Yogyakarta: Andi.

Sugiarto, T.J.R.S. 2006. Lisrel. $\quad 1^{\text {st }}$ ed. Yogyakarta: Graha llmu.

Sugiyono. 2010. Metode Penelitian Kuantitatif Kualitatif dan R\&D. $10^{\text {th }}$ ed. Bandung: CV. Alfabeta.

Wursanto, I. 2005. Dasar-dasar Ilmu Organisasi. Yogyakarta: Andi. 